\title{
Approaching globalization from the perspective of socio-economic effects
}

\author{
Catalin Razvan DOBREA \\ Bucharest University of Economic Studies, Bucharest, Romania \\ razvan.dobrea@man.ase.ro \\ Ovidiu Andrei Cristian BUZOIANU \\ Bucharest University of Economic Studies, Bucharest, Romania \\ buzoianuovidiu@yahoo.com \\ Cristina DIMA \\ Bucharest University of Economic Studies, Bucharest, Romania \\ cristina.dima@man.ase.ro \\ Evelina Petronela BALU \\ Bucharest University of Economic Studies, Bucharest, Romania \\ evelina.balu@yahoo.com
}

\begin{abstract}
The topicality of the topic lies in the importance of globalization from the perspective of sustainable development in the socio-economic and ecological sphere. Globalization cannot be considered as representing a completely new phenomenon in the history of the world, it has certain historical antecedents, many specialists arguing that it is nothing but a new name for an older phenomenon. Globalization is the global trend of the world's economies to become borderless and interconnected. Globalization has caused major damage to nature and the drying up of non-renewable resources, creating the possibility of global campaigns to develop. Civil societies are less efficient in the face of global factors, which cannot be held accountable, such as governments or companies anchored in the territory, visible and affordable.
\end{abstract}

Keywords: management, globalisation, economy, demography.

\section{Introduction}

In the new era of globalization, borders have opened up, trade barriers have been removed, and information is circulating at an unprecedented rate (Radulescu et al., 2020). The turnover of transnational companies is exploding, as is that of cross-border criminal organizations. Colossal fortunes are often the result of drug and arms trafficking, smuggling, prostitution, money laundering, all in the shadow of corruption.

Nothing that happens in our society today remains untouched by the complexity of this process. So globalization has become a symbol of the times we live in, which has both advantages and disadvantages for the countries already involved and for those to be swallowed by this wave (Bran et al., 2020).

This paper seeks to provide an image of the modern world, of economic and social changes as a result of globalization. It is dedicated to researching issues in the global economy, the evolution of economic and social gaps, global demographic trends, and environmental protection.

The choice of theme was influenced by the topicality of the phenomenon as well as by the problems involved in the process of globalization (Dobrescu, 2010). It has also created the 
possibility of global campaigns to develop. Civil societies are less efficient in the face of global factors, which cannot be held accountable, such as governments or companies anchored in the territory, visible and affordable.

The issue of globalization has economic effects not only on individuals, businessmen, governments, nation-states and state unions, with an impact on labor markets, financial markets, economic growth and convergence processes of national economies (Brecher, 2012).

Like any political and social process, globalization cannot be considered an unlimited source of benefits for humanity, especially for areas where labor productivity and efficiency are very low, but neither can it be blamed for all the evils that some social structures are forced to overcome (Dinu, 2004). However, the most important factor of globalization is the economic one, which directly influences the political factor, more precisely the policy of expansion and domination of the developed countries over the world.

The dimensions of globalization cannot be clearly delimited from each other. Global environmental issues cannot be explored in isolation from either the economic or the political dimension. Globalization encompasses more than the increased integration of the world economy, so it cannot be strictly limited to economic processes, which is often the case (Stiglitz, 2008).

\section{Literature review}

Globalization is an abstract concept, it does not materialize in a concrete object, not being highlighted by its natural dimensions, easily identifiable by established units of measurement (Radulescu, 2020). There is no indicator or statistical index obtained by mathematical calculations that can quantify the size of this phenomenon (Androniceanu et al., 2017). Due to this fact, the phenomenon is not easy to define (Dima et al., 2020). The topic of globalization first entered a dictionary in 1961. Since the mid-80s it has gained considerable circulation, joining as an adjective other terms such as: markets, institutions, ecology, finance, lifestyles, communications, migration, laws, factories, conferences, civil society, events and risks (Burlacu et al., 2020).

An answer to the question "what is globalization" we find in Ioan Bari defines globalization as a phenomenon whereby geographical distance becomes an increasingly important factor in cross-border socio-economic, socio-cultural, political and development stability (Bari, 2005). Networks of relationships and dependencies are gaining increasing potential to become international and global (Negescu et al., 2020).

Antony Giddens offers a definition containing predominantly sociological elements. "Globalization can be defined as the intensification of social relations throughout the world, which connects such distant localities to such an extent that events that take place locally are viewed through the prism of similar ones, spent many miles away and vice versa."

The World Bank defines "globalization as the observable fact that in recent years a growing share of global economic activity has taken place between individuals and firms in different countries." Globalization involves many things: an international circulation of ideas. and information, common cultural experiences, a global civil society and a common environmental movement (Ioniţă et al., 2009).

Globalization is a process of interaction and integration among people, companies and governments of different nations, a process driven by international trade and investment and aided by information technology (Held, 2016).

Globalization can best be explained as a spatial phenomenon, with two extremes: at one end are local communities with their specific problems, and at the other end is the global society we aspire to, but we do not yet know if it will ever happen (Bodislav et al., 2020). Between these 
points the whole human activity moves, in the sense that day by day it is more and more influenced by what is happening in other parts of the world, and it is influenced by the practices and decisions of local groups and communities. which may have global influences (Costache et al., 2015).

\section{Methodology}

This article aims to test the hypothesis that globalization is a decisive factor in global economic, environmental and social modeling. That said, certain statistical indicators are analyzed quantitatively, based on data provided by FAO and Worldbank. From a qualitative point of view, an analysis of some notoriety concepts from the specialized literature is used. The analysis is based on the comparative method between certain regions of the world, exposed over a wide area of time.

\section{Results and discussions}

\section{The dimensions of the globalization phenomenon}

Globalization brings with it extraordinary opportunities that have allowed some countries to capitalize on the opening of markets and the opportunity to assimilate new technologies. This is the case in several Southeast Asian countries, especially as long as they have not opened financially prematurely. In the economically advanced world, new information technologies have greatly prolonged the U.S. boom. what made some believe in the incredible virtues of the new economy and thus spoke of a new paradigm, able to combine uninterrupted economic growth with low unemployment and low inflation. Globalization can have five dimensions: economic, political, social, cultural and ecological.

The economic dimension of globalization is of great importance, it being one of the most important causes for globalization processes in other fields (huge growth of trade and direct investment, globalization of financial markets, transnational integrated production, transnational corporations, competition in local level between states and regions, end of national economies) (Ioniţă et al., 2009).

Particularly significant are the transformations produced by globalization in terms of production. The national classical corporation has today been transformed into a network, incorporating into a finished product a suite of elements collected from the farthest sources (Bergh and Gustafsson, 2019).

Markets tend to globalize due to the fact that domestic markets can no longer sustain the rising costs of research and development nor the shorter life cycles of technologically advanced products. A global production network allows firms to diversify their sources of supply and markets. to mitigate the risks assumed (Rodrik, 2018).

The ecological dimension. Some global problems, such as global warming or deforestation, most impressively illustrate the phenomenon of globalization, because in this case it is certainly global issues that require a global approach.

The social dimension. The world has become a "global village" (Bari, 2003), with innovative long-distance communication networks (chat, e-mail) adding to traditional communities such as family or neighborhood. However, they cannot replace these traditional spheres of communication.

The political dimension. This dimension refers to the "internationalization and institutionalization of political structures as a result of changes in the decision-making process to the regional and international level. Politics faces major problems. Globalization and competition at the local level limit the scope of national policies, many problems can only be properly resolved 
at the international, global level. In this sense, European integration is seen as a successful response to the challenges of globalization.

Globalization has greatly stimulated international trade and the distribution of production activities based on a logic of comparative advantage applied on a global scale, hence the rapid increase in the number of companies with global activity (Pieterse, 2015).

\section{The effects of globalization}

The reaction to a rapid and comprehensive process is not long in coming. From total rejection, fierce resistance to the critical identification of especially social implications, contemporary writings have raised globalization to the rank of the main subject.

Analyzed in terms of economic efficiency of resource allocation and use, globalization appears as a rational phenomenon, designed to provide increasing quantities of services with fewer and cheaper material, financial and human resources.

Globalization is advantageous and very advantageous for countries with high economic competitiveness: advanced technologies, efficient labor, high labor productivity, low production costs. In these conditions it can be stated that the main source of competitiveness is represented by capital (Holton, 2005). The process of globalization offers multiple and rapid advantages to developed economies, which are overwhelmingly concentrated in world capital and where large transnational companies are headquartered.

The process of globalization, in its essence, contains all the premises for widening the economic gaps existing at the end of the twentieth century between developed countries, developing countries, including former socialist states, because it globalizes only the creation of gross domestic products, without globalizing their distribution.

Today, "being local in a globalized world is a behavior of social inadequacy and degradation." For globalization to mean progress for all the states of the world, it is necessary for the developed states, which establish the international rules, to avoid understanding the representation of globalization for some and localization for others.

Markets tend to be globalized due to the fact that "internal markets can no longer sustain the rising costs of research and development, nor the shorter life cycles of technologically advanced products." (Bari, 2005).

The globalization of markets determines the "homogenization of the tastes of consumers around the world" within a market, which acquires a global character. The globalization of markets is directly related to the formation and development of multinational companies and transnational companies.

An objective analysis of the globalization process attests that economic benefits are more inclined towards developed countries and the great economic powers where transnational society finds its origin.

\section{Globalization, poverty and development inequalities}

The globalization of the economy can have beneficial effects by facilitating the access of underdeveloped countries to technologies and efficient management, ensuring on the whole an increased economic efficiency, lower costs, more products and services for consumers, new market opportunities (Bergh and Nilsson, 2014).

Countries more strongly integrated into the global economy have recorded much higher income convergence than geographically isolated countries. The greatest benefits from 
globalization have been recorded by developing countries that have integrated into the global economy, those that have chosen to actively participate in the process of globalization.

The recent financial crisis reduced the pace of poverty reduction, estimates suggest that the economic crisis pushed 64 million people into extreme poverty by the end of 2010 (Nissanke and Thorbecke, 2010).

In East Asia and the Pacific, about $14 \%$ of the population lives below \$ 1.25 a day, down from $76 \%$ in 1990 , when it was the region with the highest poverty rate in the world.

PICBE |

410

Figure 1. Peoples living on less than $\$ 1.25$ per day (million people)

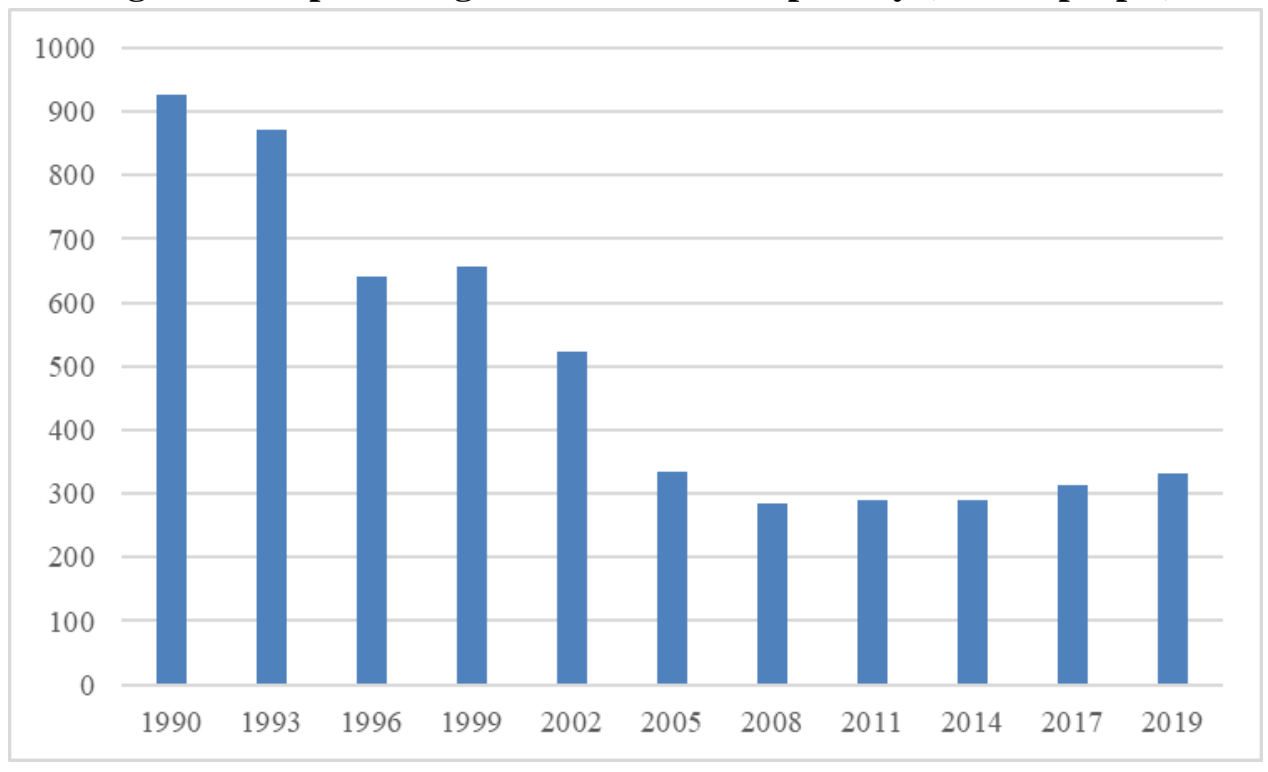

Source: WorldBank Data.

In developing countries, the extreme poverty rate was $25 \%$ in 2008 , down from $38 \%$ in 1990. In South America and the Caribbean, the poverty rate has reached its lowest level so far of $6.5 \%$ in 2019 , in 1990 being $14 \%$.

Regions such as North Africa and The Middle East had 8.6 million people or $2.7 \%$ of the population living on less than $\$ 1.25$ a day in 2008, down from 10.5 million in 2005 and 16, 5 million in 1990.

The percentage of people living on less than $\$ 1.25$ in 2019 was below $0.5 \%$ in Eastern Europe and Central Asia, after reaching 3.8 percent in 2000.

In addition to the negative effects of civilization on natural resources and environmental factors, social disparities are the most serious challenges of the $21^{\text {st }}$ century for international stability and the sustainable development of human society.

\section{Global hunger}

Agriculture and food have proven to be central to both poverty generation and poverty reduction. Malnutrition is a specific feature of poverty and is a direct violation of universal human rights (Desai and Rudra, 2018). From here start all the problems related to the standard of living: health, infant mortality, training of children in the labor force, illiteracy, poor labor productivity. The food problem is not limited to developing countries, in one way or another it affects all countries of the world, including developed ones, hence its global character. 
Hunger is a mass phenomenon, it is the most critical form of malnutrition, its consequences are catastrophic. They result in loss of life and lead to high health risks throughout life, especially children who usually do not survive. The risk of death for an underweight child, weighing twothirds of normal weight, is ten times higher than for a healthy child. Hungry babies, as well as older children or adults, are prone to infectious diseases because they do not have the energy to fight them. Hungry children are marked for life due to neurological disorders and delayed physical growth.

The problem of hunger has worsened in recent years due to rising food prices, which affects the poor as they cannot adapt to rapid change and cannot adjust their budget, eventually resorting to lower quality food or giving up products. basic in daily nutrition.

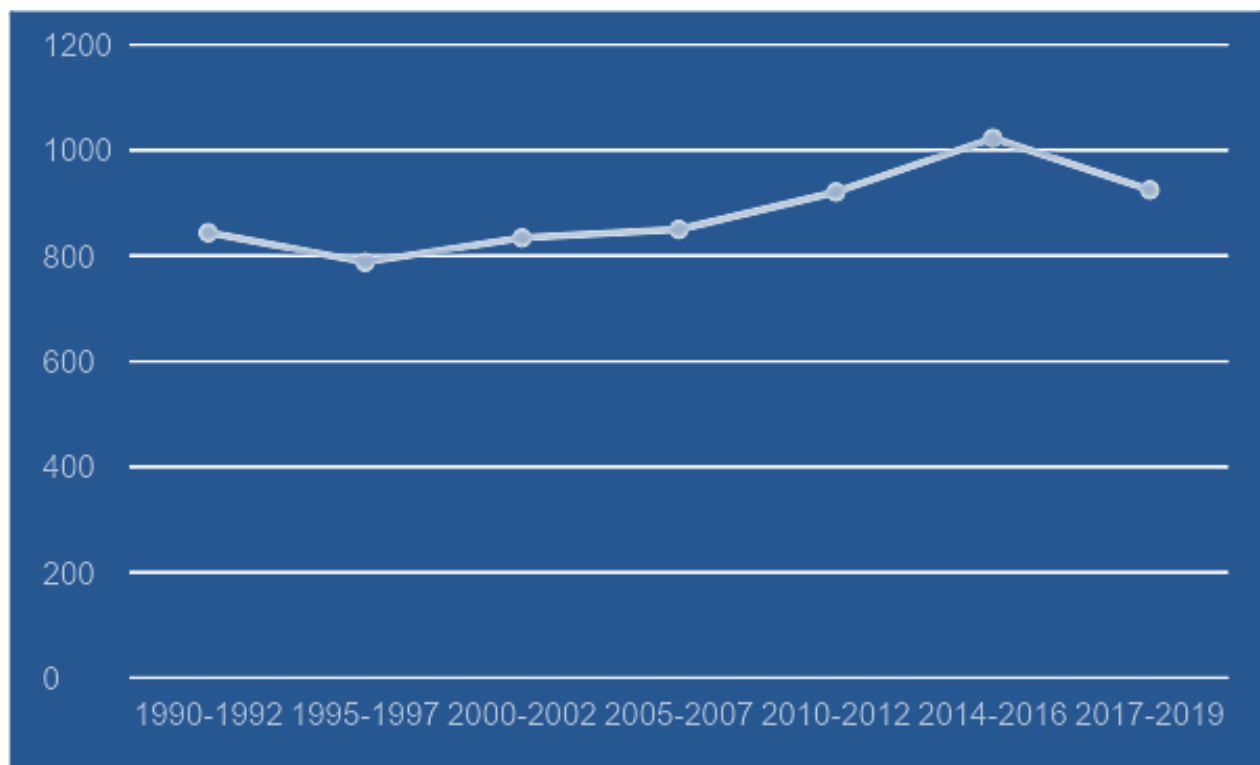

Figure 2. Number of malnourished people in the world 1996-2010 (millions of people)

Source: FAO Data- 2010-2019.

According to the FAO, there has been a certain decline in the number of undernourished people in recent decades. In 2019, 925 million people were registered in a state of chronic hunger, compared to 844 million people in the period 1990-1992.

A total of 921 million people are malnourished in 2010, compared to 1.23 billion in 2009, although almost one in six people suffer from hunger, which is still higher than before the food and economic crises in 2008-2009 and above the level that existed when world leaders agreed to halve the number of people suffering from hunger.

The explanation for this decline is explained by a favorable economic environment in 2010, especially in emerging countries, as well as the fall in food prices from 2008 to the present.

Of the malnourished, $98 \%$ live in developing countries and two-thirds live in just seven countries (Bangladesh, China, the Democratic Republic of the Congo, Ethiopia, India, Indonesia and Pakistan), and over $40 \%$ live in China and India. 


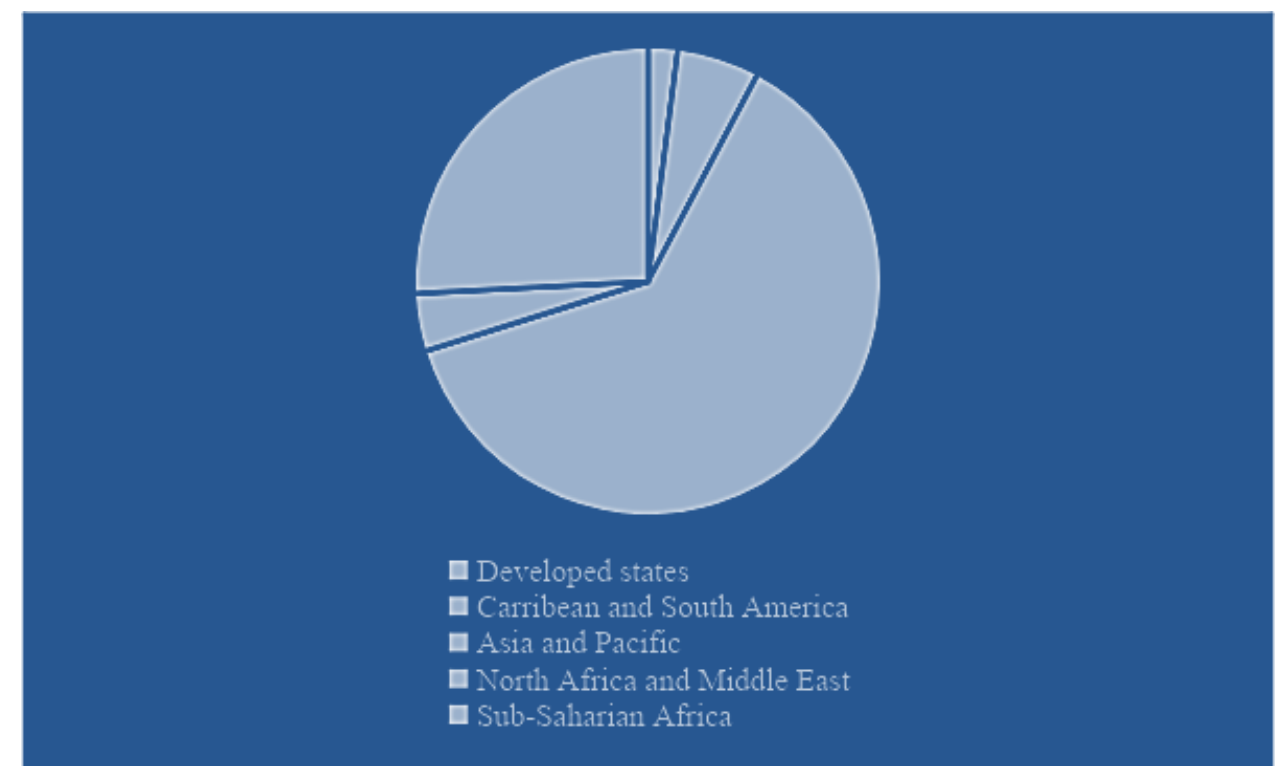

PICBE |

Figure 3. Undernourished people in 2019 by region (millions)

Source: FAO Data 2010-2019.

The most malnourished region continues to be Asia and the Pacific, but down 12 percent from 658 million people in 2009 to 578 million, followed by South Saharan Africa (239 million), Latin America and the Caribbean-53 million), and the North Africa and Middle East (37 million).

\section{Conclusions}

Long discussed and analyzed, globalization has today become an objective phenomenon, unprecedented in universal history, through its magnitude and evolution. Criticized by some, glorified by others, globalization is following in its footsteps. This controversial process consists, in essence, in the stronger integration of countries and their populations as a result of the significant reduction of transport and communication costs and the elimination of barriers to the movement of goods, services, capital, knowledge and people between states.

Globalization can be a force for good: it has brought hundreds of millions of people to a higher standard of living; the globalization of the economy has benefited the countries that have taken advantage of it by identifying new export markets and attracting foreign investment.

The growth of international trade, massive international financial flows, and the activities of multinational corporations are increasingly closely linked to each other's world economies, making globalization a controversial feature of the world economy.

Thanks to a complicated network of mechanisms, processes, such as the rapid unification of markets and capital and technological processes, accelerated by the combination of computers, telecommunications satellites and submarine and fiber optic cables, globalization has reached its highest stage today.

We are currently witnessing a global reconfiguration in which US supremacy is gradually giving way to new powers rising at the beginning of this $21^{\text {st }}$ century. The new foreshadowed global order does not lead to an anti-American world, the US still dominating the economy and geopolitics of tomorrow's world. We can speak, rather, of a post-American world, in which the G20 member 
countries (Group of 20) will consolidate the future multipolarity, and the G2 formed by the USA and China will mean progress or the new world division.

China's growing role in global economics and geopolitics forces us to look at China from a new perspective: an emerging world power capable of influencing the effects and duration of the economic crisis and a world power that plays an important role in the world geopolitical scene with consequences that are difficult to predict and at the same time difficult to accept.

PICBE |

\section{References}

Androniceanu, A., Burlacu, S., Drăgulănescu, I. V., \& Nicolae, E. E. (2017, May). New trends of businesses digitalization in Romania and the behaviour of young consumers. In BASIQ International Conference: New Trends in Sustainable Business and Consumption, Graz, Vol. 31, 27-35.

Bari, I. (2003). Contemporary global issues, Editura Economica, Bucuresti.

Bari, I. (2005). Globalization and global issues, Editura Economica, Bucuresti.

Bergh, A., Gustafsson, A. (2019). Globalization and Populism in Europe, SSRN Electronic Journal.

Bergh, A., Nilsson, T. (2014). Is globalization reducing absolute poverty? World Development 62, 42-61.

Bodislav, D.A., Radulescu, C.V., Bran, F., and Burlacu, S. (2020). Public Policy in the Areas of Environment and Energy. $6^{\text {th }}$ BASIQ International Conference on New Trends in Sustainable Business and Consumption. Messina, Italy, 4-6 June 2020. Bucharest: ASE, 228-235.

Bran, F., Rădulescu, C. V., Bodislav, D. A., \& Burlacu, S. (2020). Environmental risks in the context of globalization, Economic Convergence in European Union, 350.

Brecher, J. (2012). De-centering globalization from below. Social Policy 42(2): 30-34.

Burlacu, S., Vasilache, P. C., Velicu, E. R., Curea, Ș. C., \& Margina, O. (2020, December). Management of Water Resources at Global Level, In Proceedings of the International Conference on Economics and Social Sciences, 998-1009. Sciendo.

Costache, G., Marinas, C. V., Igret, R., \& Burlacu, S. (2015). Internship in the Hr DepartmentOrganizational and Individual Perspectives, In Proceedings of the International Management Conference, 9(1), 359-370, Faculty of Management, Academy of Economic Studies, Bucharest, Romania.

Desai, R. M, Rudra, N. (2018). Trade, poverty, and social protection in developing countries, European Journal of Political Economy.

Dima, C., Burlacu, S., \& Buzoianu, O. A. C. (2020). Strategic Options for the Development of Ecotourism in the Danube Delta in the Context of Globalization, In SHS Web of Conferences, Vol. 74, 04005. EDP Sciences.

Dinu, M. (2004). Globalizarea si aproximarile ei, Editura Economica, Bucuresti.

Dobrescu, P. (2010). Viclenia globalizarii, Institutul European, Iasi.

Held, D. (2016). Elements of a theory of global governance, Philosophy \& Social Criticism, 42(9), 837-846.

Holton, R. J. (2005). Making Globalisation, Basingstoke, Palgrave Macmilla.

Ioniță, F., \& Burlacu, S. (2009). Public Administration from Romania in the Knowledge Society and E-Learning, In Proceedings of the Fifth" Administration and Public Management" International Conference:" Public Institutions' Capacity to Implement the Administrative Reform Process", Bucharest, June 23-24, No. 25. 
Ioniţă, F., Burlacu, S., \& Gaidargi, A. (2009). Modern Approaches of the Management of Alternative Trade Systems, Revista de Management Comparat Internațional / Review of International Comparative Management, 51, 473-480.

Negescu, M. D., Burlacu, S., Mitriţă, M., Buzoianu, O. C. A. (2020). Managerial Analysis of Factoring at the International Level Challenges of the Contemporary Society. Proceedings; Cluj-Napoca, 13(1), 99-102. Cluj-Napoca: Babes Bolyai University.

Nissanke, M., Thorbecke, E. (2010). Globalization, poverty, and inequality in Latin America: Findings from case studies, World Development 38(6), 797-802

Pieterse, J. N. (2015). Globalization and Culture: Cultural Melange, $3^{\text {rd }}$ edn. Lanham, MD, Rowman \& Littlefield. 13.

Radulescu D., (2007). Probleme globale contemporane, Editura Universitatii Petrol-Gaze.

Rădulescu, C. V., Bran, F., Burlacu, S., Dobrea, C. R., \& Diaconu, S. (2020, December). Challenges Regarding Food Resources in the Context of Globalization and Population Growth, In Proceedings of the International Conference on Economics and Social Sciences, 1041-1052, Sciendo.

Rădulescu, C. V., Burlacu, S., Bodislav, D. A., \& Bran, F. (2020). Entrepreneurial Education in the Context of the Imperative Development of Sustainable Business, European Journal of Sustainable Development, 9(4), 93-93.

Radulescu, C.V., Ladaru, G.-R., Burlacu, S., Constantin, F., Ioanăș, C., Petre, I.L. (2021). Impact of the COVID-19 Pandemic on the Romanian Labor Market, Sustainability 2021, 13, 271. https://doi.org/10.3390/su13010271.

Rodrik, D. (2018). Populism and the Economics of Globalization, Journal of International Business Policy, Vol. 1.

Stiglitz, J. (2008). Mecanismele globalizarii, Editura Polirom, Iasi. 